\title{
Sugarcane Plant Growth and Physiological Responses to Soil Salinity during Tillering and Stalk Elongation
}

\author{
Duli Zhao ${ }^{1, *}$, Kai Zhu ${ }^{1,2}$, Aliya Momotaz ${ }^{1}$ and Xinxin Gao ${ }^{3}$ \\ 1 USDA-ARS, Sugarcane Field Station, Canal Point, FL 33438, USA; \\ Kai.zhu@usda.gov or zhukai0202@gmail.com (K.Z.); Aliya.momotaz@usda.gov (A.M.) \\ 2 College of Agriculture, Guangxi University, Nanning 530004, Guangxi, China \\ 3 Yunnan Sugarcane Research Institute, Yunnan Academy of Agricultural Sciences, \\ Kaiyuan 661699, Yunnan, China; xinlshuai@163.com \\ * Correspondence: duli.zhao@usda.gov; Tel.: +1-561-924-5227
}

Received: 25 October 2020; Accepted: 5 December 2020; Published: 8 December 2020

\begin{abstract}
A pot study was conducted to investigate influences of salinity on sugarcane (Saccharum spp.) plant growth, leaf photosynthesis, and other physiological traits during tillering and stalk elongation. Treatments included two commercial sugarcane cultivars (Canal Point (CP) 96-1252 and CP 00-1101) and an Erianthus with five different soil salt concentrations (0 [Control], 38, 75, 150, and $300 \mathrm{mM}$ of $\mathrm{NaCl}$ added). Growth (tillers, plant height, and nodes) and physiological (leaf net photosynthetic rate $[\mathrm{Pn}]$, stomatal conductance $\left[\mathrm{g}_{\mathrm{s}}\right]$, intercellular $\mathrm{CO}_{2}$ concentration, and leaf water soluble sugar concentrations) characters were determined during the experiment. Responses of sugarcane growth, photosynthesis, and photoassimilate translocation to salinity depended on soil salt concentration. Plant height was the most sensitive while the number of nodes was the most tolerant to soil salinity among the three growth traits measured. CP 96-1252 differed from CP 00-1101 significantly in response of shoot:root ratio to high salt concentration. Leaf Pn of plants treated with the $38 \mathrm{mM}$ salt did not differ from that of the control plant, but plants treated with the 75, 150, and $300 \mathrm{mM}$ salt had 12.7, 18.7, and 35.3\% lower leaf Pn, respectively, than the control. The low leaf Pn due to salinity was associated with not only the decrease in $\mathrm{g}_{\mathrm{s}}$, but also the non-stomatal factors. Results of leaf sugar composition and concentrations revealed that high salt concentration also depressed photoassimilate translocation from leaves to other plant tissues. These findings are important for better understanding of some physiological mechanisms of salinity influence on sugarcane growth and yields.
\end{abstract}

Keywords: salinity; sugarcane growth; leaf photosynthesis; photo-assimilate translocation; dry matter accumulation and partitioning; shoot to root ratio

\section{Introduction}

Soil salinity is one of stress factors limiting crop growth and yield in many regions of the world [1,2]. Salinity is a soil condition in most arid and semiarid regions [3,4]. Ions contributing to soil salinity mainly include $\mathrm{Cl}^{-}, \mathrm{SO}_{4}{ }^{2-}, \mathrm{HCO}_{3}{ }^{-}, \mathrm{Na}^{+}, \mathrm{Ca}^{2+}$, and $\mathrm{Mg}^{2+}$ [5]. Saline soils contain soluble salts in quantities that adversely affect plant growth when the soil electric conductivity (EC) reaches a certain level. However, plant tolerances to saline vary widely from soil to soil and from salt type to salt type [5] as well as differences among crop species and growth stages. Crop species show the big differences in tolerance to salinity [5-7].

The effects of salinity stress on plant phenotype were characterized by stunted, slow growth, leaf area reduced, succulent, and maybe dead in severe cases [8]. There are many changes in physiological parameters when plants exposed to salinity conditions. For instance, high salinity reduces the ability of plants to absorb water, ionic toxicity injures cells in the transpiring leaves, and stomatal 
closure reduces transpiration eventually decreases photosynthetic rate [9-11]. These factors should be responsible for plant growth reduction. Crops normally respond to salt stress in various ways, and some of the positive responses are the excellent characteristics of salinity-tolerant varieties. Among these responses, the regulation of membrane system, the change of cell wall structure, and the reconstruction of cell REDOX level through osmotic adjustment are important functions to cope with salinity stress $[12,13]$. In addition, gene regulation and epigenetic inheritance regulation including histone modification, DNA methylation and changes in the distribution of nucleosomes also contribute to salinity tolerance at the molecular level [14]. There are numerous basic and applied studies and reports for field crop responses to soil salinity. However, research on growth and physiological effects of saline in sugarcane (a complex hybrid of Saccharum spp.) is much less as compared to other crops.

In an early report, sugarcane had very low rate of foliar salt absorption [15] as compared with other crops. When sugarcane plants were exposure to saline condition during the grant growth (180 days after sowing), the number of millable stalks, stalk length, and stalk weight were reduced [16]. Wahid et al. [1] evaluated nine sugarcane lines to identify salt tolerance traits in Pakistan and found that sugarcane lines showing xeric characters were better able to tolerate high salinity. In 2013, Christy et al. [17] investigated biochemical and molecular parameters by analyzing leaf pigment, protein, proline, activities of peroxidase and super oxide dismutase (SOD), lipid peroxidation, peroxidase, superoxide dismutase, and total RNA for salt tolerant and susceptible genotypes of sugarcane under non-saline and saline conditions. They reported that the tolerant genotypes expressed better stability in these parameters than the sensitive genotypes [17]. Moreira et al. [18] in 2020 found that spraying solutions consisting of glyphosate with the carboxylic compounds (MTD) insecticide and ethephon are the most technically effective way to enhance sugarcane performance adequately under uncontrollable or unpredictable agro-ecosystems for natural ripening in marginal lands with drought, heat, salinity, and other unfavorable conditions.

In the United States, soil salinity caused the reduction in sugarcane juice quality in Louisiana [19] and high salt concentration in irrigation water was also an issue for sugarcane growth and yield formation in Texas [20]. In the USDA-ARS Canal Point (CP) sugarcane breeding and cultivar development program in Florida, all parental plants are grown in pots with more than 3000 pots annually and watered using the dripping irrigation system with ground water [21]. High concentration of salt in irrigation water pumped from a well at Canal Point $\left(26.91^{\circ} \mathrm{N}, 80.61^{\circ} \mathrm{W}\right)$, may cause some issues in growth and flower development for the potted parental plants [22]. Several studies have indicated that there are big variations in responses to salinity among sugarcane genotypes as well as at different growth stages. However, most of these previous studies mainly focused on leaf chlorosis, necrosis, plant death, and growth traits, such as plant height, number of leaves, and biomass accumulation $[1,4,16,23]$.

Sugarcane is a $\mathrm{C} 4$ plant to assimilate air $\mathrm{CO}_{2}$. Leaf area index (LAI) and leaf net photosynthetic rate $(\mathrm{Pn})$ are two major contributors of plant growth and dry matter accumulation [24]. Salinity is one of essential factors that directly or indirectly influence LAI and/or leaf Pn [25]. In addition, at a certain leaf area, leaf $\mathrm{Pn}$ is associated with several physiological parameters, such as stomatal conductance $\left(\mathrm{g}_{\mathrm{s}}\right)$, intercellular $\mathrm{CO}_{2}$ concentration ( $\mathrm{C} i$ ), and photo-assimilate enzyme activities (non-stomatal factors). However, these physiological and biochemical mechanisms of sugarcane plant responses to salt stress are limited. Erianthus [Erianthus arundinaceus (Rez.) Jeswiet] has been used to make crosses with sugarcane in order to improve sugarcane stress tolerance [26]. However, it is unclear if there are any differences between sugarcane and Erianthus in response to salinity stress. We hypnotized that some physiological differences might exist among sugarcane genotypes or between sugarcane and Erianthus.

To test our hypothesis of differences among sugarcane genotypes and between sugarcane and Erianthus plants in growth and physiological responses to salinity stress, an outdoor pot study was carried out at the United States Department of Agriculture (USDA)-ARS Sugarcane Field Station, Canal Point, Florida. Specific objectives of this study were: (i) to determine sugarcane plant growth and 
physiological responses to soil salt concentrations; (ii) to investigate genotypic differences in response to salinity; and (iii) to identify if there are any interaction between genotype and salt concentration.

\section{Materials and Methods}

\subsection{Plant Culture and Treatments}

Stalk node growth buds (eye pieces) of two commercial sugarcane cultivars, 'CP 96-1252' [27] and ' $\mathrm{CP} 00-1101$ ' [28] and a genotype of Erianthus were planted in pots on 12 October 2017. The two sugarcane cultivars were top commercial varieties in the Florida sugarcane production [29] because CP 96-1252 was tolerant to changes in growth environment, especially nutrients and water with a good ratooning ability and CP 00-1101 had high stalk sucrose content. These two sugarcane cultivars have diverse characters in flowering and rust disease reaction. CP 96-1252 is an early flowering cultivar with resistance to orange rust, but susceptibility to brown rust. In contrast, $\mathrm{CP}$ 00-1101 is a non-flowering cultivar with resistance to brown rust, but susceptibility to orange rust in Florida. According to Berding and Roach [26], Erianthus is a large grass with tall and big stalks, which has useful agronomic traits with tolerance to some stress environment [30] and disease resistance that are desired and interested in sugarcane breeding programs by sugarcane breeders. The single-bud stalk sections of each genotype were planted in pots ( $38 \mathrm{~cm}$ in both diameter and height) with six small holes at the pot base and filled with a potting soil mixed with new peat and pine bark fines and $5 \%(\mathrm{wt})$ fine sand (Florida Potting Soils, Orlando, FL, USA). An amount of $12.5 \mathrm{~g}$ of Osmocote classic controlled release fertilizer $\left(\mathrm{N}-\mathrm{P}_{2} \mathrm{O}_{5}-\mathrm{K}_{2} \mathrm{O}\right.$ = 14-14-14) was applied to each pot at planting time (12 October 2017). To ensure consistent conditions of soil, water, and nutrients for all pots before the salt treatments, six stalk sections (eye pieces) of the same genotype were planted in each pot. Only two uniformed young plants per pot were retained by thinning at 50 days after planting (DAP). Sixty pots were arranged on an outdoor can line area with dripper watering system (Figure 1) under ambient conditions. In the Florida sugarcane production area (around Lake of Okeechobee), winter is mild and the minimum temperature has never dropped to $0{ }^{\circ} \mathrm{C}$ since 2011. There was not any cold issue for sugarcane growth during the experiment.

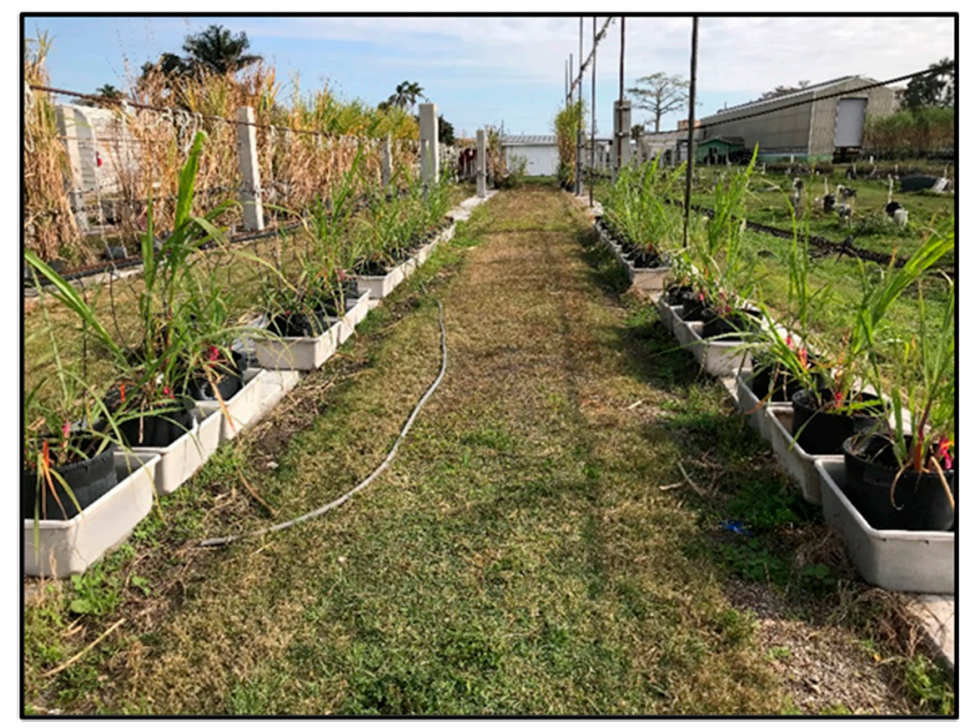

Figure 1. Potted plants of two sugarcane cultivars (Canal Point (CP) 00-1101, CP 96-1252) and an Erianthus in the containers for different salinity treatments.

Ten days (14th November) before salinity treatments, all pots were placed into individual containers that were applied for desired water and salinity treatments by keeping a 4-cm depth of water level daily (Figure 1). Starting from this point, water supply for all pots from the containers by adding water daily rather than drippers. Five treatments of salt concentrations were: 0 (control, 
natural tap water), 38, 75, 150, and $300 \mathrm{mM}$ of $\mathrm{NaCl}$ by adding certain amount of $\mathrm{NaCl}$ in water in the containers three times equally split. The salinity treatments started 53 DAP with one third (1/3) amount of the proposed $\mathrm{NaCl}$. The second and third times of salt added were at 69 and $99 \mathrm{DAP}$, respectively. The pot study was completed at 200 DAP. Thus, plants grew for 147 days under the designed salinity conditions (from 53 through 200 DAP). During the experiment, the water electrical conductivity (EC) and $\mathrm{pH}$ in the containers were monitored weekly using a 556 Handheld Multi-parameter Instrument (YSI Incorporated, Yellow Springs, OH, USA). The EC values of five salinity treatments of $0,38,75,150$, and $300 \mathrm{mM}$ were $1.07 \pm 0.04,3.83 \pm 0.21,5.67 \pm 0.36,10.34 \pm 0.63$, and $20.77 \pm 1.03 \mathrm{~ms} / \mathrm{cm}$, respectively; the $\mathrm{pH}$ values were $7.85 \pm 0.04,7.98 \pm 0.21,7.86 \pm 0.02,7.88 \pm 0.03$, and $8.08 \pm 0.03$, respectively.

\subsection{Measurements}

During the salinity treatment, plant height, the numbers of nodes and tillers, leaf relative chlorophyll level (SPAD reading), and the Photosystem II efficiency (i.e., Quantum Yield, QY) of photosynthesis were determined on biweekly bases. The number of nodes (or leaves) and plant height were measured on the primary stalk from initiation of the salinity treatment (53 DAP) through the end of the experiment (200 DAP). The SPAD readings and QY were measured on the top visible dewlap (TVD) leaves (i.e., uppermost fully expanded leaf) of the primary stalks. Leaf SPAD readings were measured with a Minolta 502 SPAD meter (Minolta Co., LTD., Osaka, Japan). The QY measurements were taken on the light-adapted leaves from all plants at 11:00 am East Time using a FluroPan FP-100 fluorescence meter (Photon System Instruments, Drasov, Czech Republic).

Leaf photosynthetic components, including leaf net photosynthetic rate (Pn), stomatal conductance $\left(\mathrm{g}_{\mathrm{s}}\right)$, intercellular $\mathrm{CO}_{2}$ concentration $(\mathrm{C} i)$, and leaf transpiration rate $(\mathrm{E})$, were measured three times monthly between 1030 and $1300 \mathrm{~h}$ from the TVD leaves to determine effects of $\mathrm{NaCl}$ concentration on leaf photosynthesis characteristics and genotype differences in response to the salinity. An LI-6400XT portable photosynthesis system (LI-COR Inc., Lincoln, NE, USA) was used to measure leaf photosynthetic components according to Zhao et al. [30]. The photosynthetically active radiation in the leaf chamber was set to $1500 \mu \mathrm{mol} \mathrm{m} \mathrm{m}^{-2} \mathrm{~s}^{-1}$, relative humidity was adjusted to near ambient level (approximately 70\%), and leaf chamber $\mathrm{CO}_{2}$ concentration was set to $380 \mu \mathrm{L} \mathrm{L}^{-1}$ during measurements of leaf photosynthesis.

In addition, fresh leaf disc samples were collected at 135 DAP from the TVD leaves to determine chlorophyll and nonstructural carbohydrate concentrations according to Zhao and Oosterhuis [31] and Zhao et al. [32]. At the end of the experiment (200 DAP, 2 May 2018, prior to hurricane season), all plants were harvested and dry biomass data of aboveground shoot components (green leaves, brown leaves, stalks) and roots were determined using a standard procedure of plant growth analysis [33].

\subsection{Experimental Design and Data Analyses}

The experiment was a split plot design with four replications (i.e., 4 replicated pots for each of 15 treatments). Salt concentration was set as the main plot and genotype was as the subplot. To test plant genotype differences in response to salt concentration and to compare leaf photosynthetic components between the non-salt added control and salinity treatments, significance of each fixed effect was analyzed using the MIXED procedure of SAS [34]. Replication was considered as a random effect and genotype and salinity were considered as fixed effects. Measurement dates for Pn of the TVD leaves were considered as repeated measurements. If the hypothesis of equal means for a measured variable between treatments was rejected by the $F$ test, then data means were separated with the LSD at $p=0.05$. The LSD values were calculated with the standard error (SE) values generated by the Diff option in the SAS MIXED procedure [34]. 


\section{Results and Discussions}

\subsection{Plant Height, Nodes, and Tillers}

Plant height, the number of nodes, and tillers of CP 00-1101, CP 96-1252, and Erianthus were measured on the primary stalks of individual plants during the salinity treatment (Figure 2). Overall, there were no interactive effects of genotype and salt concentration on any of the three growth traits. Therefore, the main effects of genotype and salinity were further analyzed.
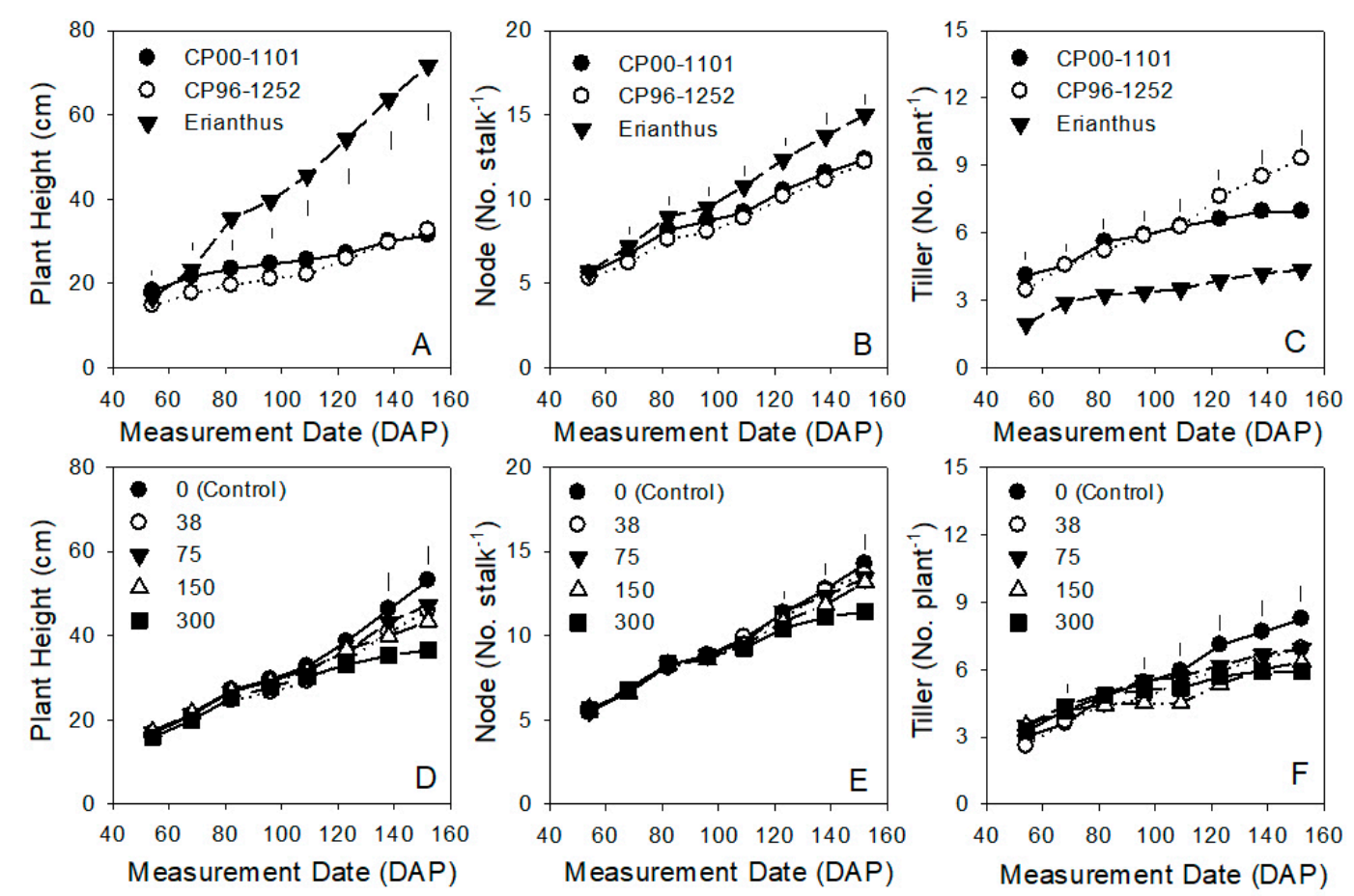

Figure 2. Plant height, the number of nodes measured on the primary stalk, and the number of tillers per plant for two sugarcane cultivars (CP 00-1101, CP 96-1252) and an Erianthus as affected by salinity treatments [0 (Control), 38, 75, 150, and $300 \mathrm{mM}$ of $\mathrm{NaCl}$ added]. Vertical Bars indicate $\mathrm{LSD}_{0.05}$ values if the main effects of $(\mathbf{A}-\mathbf{C})$ genotype or $(\mathbf{D}-\mathbf{F})$ salinity treatment are significant $(p \leq 0.05)$ at a specific measurement time.

Compared to sugarcane, Erianthus had significantly taller plant height and more stalk nodes (Figure 2A,B), but much less number of tillers (Figure 2C). There were no differences between CP 00-1101 and CP 96-1252 in plant height or the number of nodes at most measurement dates. However, CP 96-1252 had significantly more tillers than CP 00-1101 starting from 120 DAP (Figure 2C). Our results of more tillers in CP 96-1252 than that in CP 00-1101 in this study are in agreement with the good ratooning ability of CP 96-1252, a top commercial cultivar in the Florida sugarcane production [29].

Salinity had little effect on plant height before 120 DAP because there were no statistical differences among the salt concentration treatments until 140 DAP (Figure 2D). At 152 DAP, the plants with salt treatments of $38,75,150$, and $300 \mathrm{mM}$ had 13.5, 11.1, 18.3, and 31.0\%, respectively, shorter plant height than the control plants. There were not any differences in the number of nodes among the 0 (control), 38 , and $75 \mathrm{mM}$ salt treatments during the experiment. Starting from $150 \mathrm{DAP}$, however, the 150 and $300 \mathrm{mM}$ salt treatments had statistically less nodes than the control on the primary stalks (Figure 2E). Among the three growth traits (plant height, the number of nodes, and tillers), the number of tillers was the most sensitive trait to salinity treatments (Figure 2F) and all salt treatments had significantly less tillers than the control, staring from 110 DAP onward. Previous studies have reported that sugarcane varieties differed greatly in respond to salinity in plant height and dry matter production $[1,23]$. In the 
present study, the two sugarcane cultivars had no big differences in response to salt concentration during early growth and tillering stages.

\subsection{Leaf SPAD Readings and Chlorophyll QY}

Leaf relative chlorophyll levels (SPAD readings) ranged from 29.1 to 51.6, depending mainly on genotype and measurement date (Figure 3A,C). CP 96-1252 (42.0, averaged over measurement dates) had significantly greater SPAD readings than both CP 00-1101 (35.3) and Erianthus (34.8), although the time course is similar among the three genotypes (Figure 3A). There were no statistical differences among the salinity treatments in SPAD readings at most measurement dates (Figure 3C). Although leaf chlorosis, necrosis, and even death were observed in saline susceptible sugarcane varieties under salt stress conditions in hydroponic medium in a previous study [23], our pot study indicated that there were no any differences among the salinity treatments in the leaf area based chlorophyll $a$, chlorophyll $b$, and carotenoid concentrations in the laboratory chemical analysis at 134 DAP.
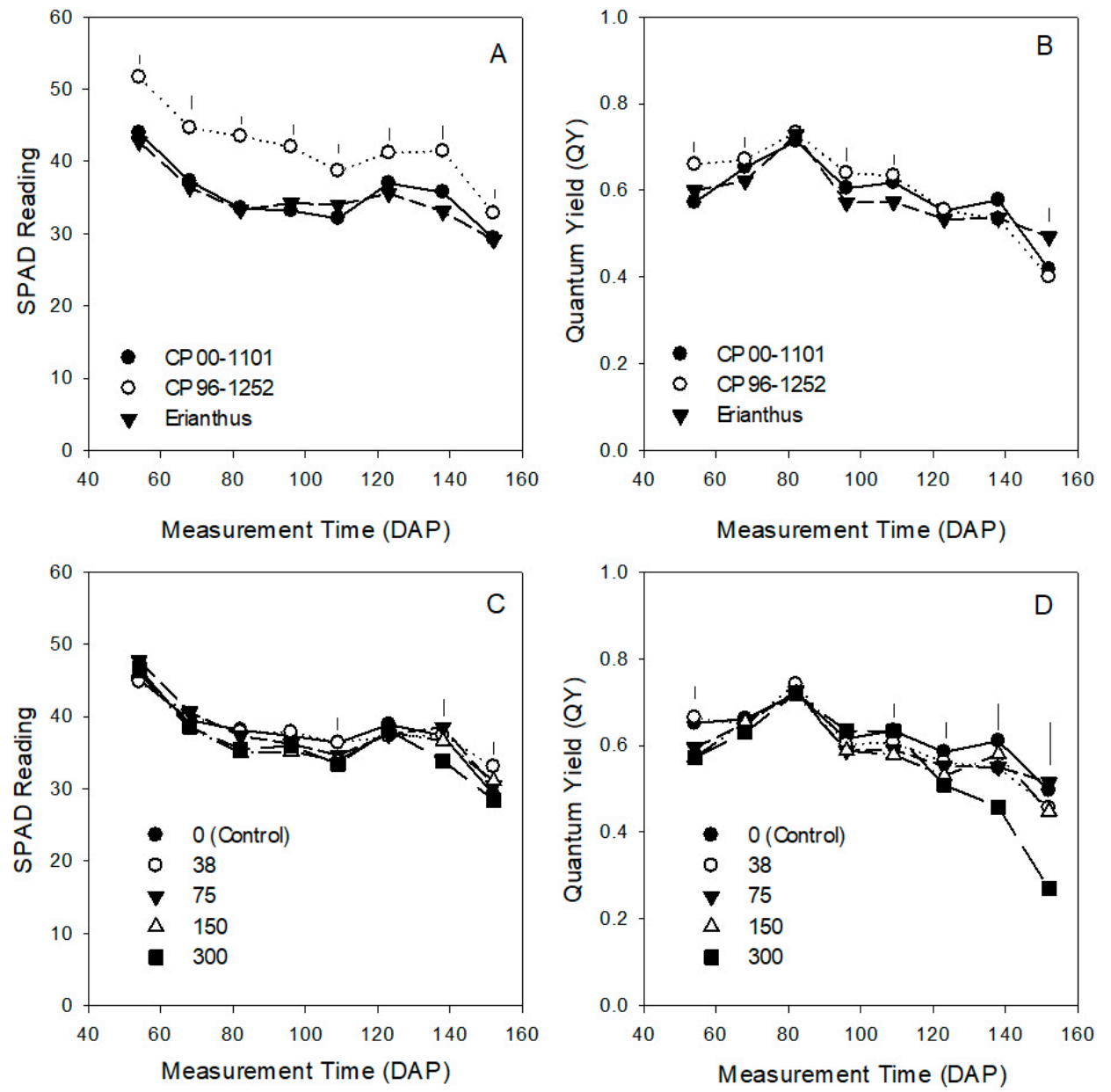

Figure 3. Leaf relative chlorophyll level (SPAD readings) and chlorophyll fluorescence parameter quantum yield (QY) of two sugarcane cultivars (CP 00-1101, CP 96-1252) and an Erianthus as affected by salinity treatments [ 0 (Control), 38, 75, 150, and $300 \mathrm{mM}$ of $\mathrm{NaCl}$ added]. Vertical Bars indicate $\mathrm{LSD}_{0.05}$ values if the main effects of $(\mathbf{A}, \mathbf{B})$ genotype or $(\mathbf{C}, \mathbf{D})$ salinity treatment are significant $(p \leq 0.05)$ at a specific measurement time.

It has been reported that salinity significantly reduced Photochemical efficiency of PSII (Fv/Fm) in sorghum (Sorghum bicolor L.) [35], wheat (Triticum aestivum L.) [36,37], and barley (Hordeum vulgare L.) [38]. In the present study, leaf chlorophyll fluorescence parameter QY was the highest around 
80 DAP and slowly declined as plants grew (Figure 3B,D). There were no consistent differences among the three genotypes tested in this study. Averaged across measurement dates, the QY values of the light adapted leaves were 0.59, 0.60, and 0.58, respectively, for CP 00-1101, CP 96-1252, and Erianthus. Starting from $120 \mathrm{DAP}$, the leaves of the 150- and 300-mM treated plants had significantly lower QY than the control and/or 38-mM treated plants (Figure 3D). The QY values of the control, 38, 75, 150, and $300 \mathrm{mM}$ treatments were 0.50, 0.46, 0.51, 0.45, and 0.27, respectively, at $152 \mathrm{DAP}$ (Figure 3D). These results indicated that salinity stress mainly influenced chlorophyll photosynthetic efficiency rather than chlorophyll concentration on the leaf area basis. Therefore, chlorophyll fluorescence may be a better indicator than chlorophyll content for detecting salinity stress and could be potentially used to screen salinity tolerance [38].

\subsection{Leaf Photosynthesis Characters}

Leaf net photosynthetic rate $(\mathrm{Pn})$, stomatal conductance $\left(\mathrm{g}_{\mathrm{s}}\right)$, intercellular $\mathrm{CO}_{2}$ concentration (Ci), and leaf transpiration rate (E) were determined three times (71, 117, and $134 \mathrm{DAP})$ during the experiment (Table 1). Results indicated that there were no differences among CP 00-1101, CP 96-1252, and Erianthus in $\mathrm{Pn}, \mathrm{g}_{\mathrm{s}}$, or E, while the difference was detected among the three genotypes in Ci. Vasantha et al. [39] also reported that either leaf Pn or E did not differ under salt conditions in the early growth stage among contracting sugarcane genotypes.

Table 1. Leaf net photosynthetic rate $(\mathrm{Pn})$, stomatal conductance $\left(\mathrm{g}_{\mathrm{s}}\right)$, intercellular $\mathrm{CO}_{2}$ concentration (Ci), and transpiration rate (E) of two sugarcane cultivars (CP 00-1101, CP 96-1252) and an Erianthus as affected by salt $(\mathrm{NaCl})$ concentration $(\mathrm{mM})$ with analysis of variance (ANOVA) of genotype and salt main effects and their interactions ${ }^{\dagger}$.

\begin{tabular}{|c|c|c|c|c|c|}
\hline & & Pn & $g_{s}$ & $\mathrm{C} i$ & E \\
\hline & & $\left(\mu \mathrm{mol} \mathrm{m} \mathrm{m}^{-2} \mathrm{~s}^{-1}\right)$ & $\left(\mathrm{mol} \mathrm{m}^{-2} \mathrm{~s}^{-1}\right)$ & (ppm) & $\left(\mathrm{mmol} \mathrm{m} \mathrm{m}^{-2} \mathrm{~s}^{-1}\right)$ \\
\hline \multirow[t]{3}{*}{ Genotype } & СР 00-1101 & 25.85 & 0.181 & $144.6 \mathrm{~b}$ & 3.014 \\
\hline & СР 96-1252 & 23.56 & 0.174 & $157.8 \mathrm{a}$ & 2.873 \\
\hline & Erianthus & 26.67 & 0.178 & $127.8 \mathrm{c}$ & 2.990 \\
\hline \multirow[t]{5}{*}{ Salt treatment } & 0 (Control) & $29.55 \mathrm{a}^{\ddagger}$ & $0.209 \mathrm{a}$ & 141.6 & $3.396 \mathrm{a}$ \\
\hline & 38 & $28.29 \mathrm{ab}$ & $0.196 \mathrm{ab}$ & 141.7 & $3.221 \mathrm{ab}$ \\
\hline & 75 & $25.79 \mathrm{bc}$ & $0.175 \mathrm{~b}$ & 138.9 & $2.949 \mathrm{bc}$ \\
\hline & 150 & $24.02 \mathrm{c}$ & $0.166 \mathrm{bc}$ & 147.2 & $2.808 \mathrm{c}$ \\
\hline & 300 & $19.13 \mathrm{~d}$ & $0.144 \mathrm{c}$ & 147.7 & $2.421 \mathrm{~d}$ \\
\hline \multirow[t]{3}{*}{ ANOVA $\S$} & Genotype (G) & $\mathrm{ns}$ & ns & $* * * *$ & $\mathrm{~ns}$ \\
\hline & Salt (S) & $* * * *$ & $* * * *$ & ns & $* * * *$ \\
\hline & $\mathrm{G} \times \mathrm{S}$ & ns & ns & ns & ns \\
\hline
\end{tabular}

${ }^{+}$Data are averages of three measurement dates $\left(71,117,134\right.$ days after planting) and four replications. ${ }^{\ddagger}$ The data values within a variable followed by the same letters are not significant $(p>0.05)$. $\$$ The ns and ${ }^{* * * *}$ indicate not significant $(p>0.05)$ and significant at $p \leq 0.0001$ level, respectively.

There are no specific reports in responses of sugarcane leaf photosynthetic parameters to soil salinity or salt concentration, although this kind of studies has been carried out on sugar beet (Beta vulgaris spp. vulgaris) [40], maize (Zea mays L.) [41], and other many field crops [42]. In the present study, we found that salinity significantly impacted on all other photosynthesis parameters except for $\mathrm{C} i$ (Table 1). There were no interactions in these homothetic traits between genotype and salt treatment. Leaf Pn, $\mathrm{g}_{\mathrm{s}}$, and E declined as the soil salt concentration increased. Leaf Pn, $\mathrm{g}_{\mathrm{s}}$, and $\mathrm{E}$ of the $300 \mathrm{mM}$ treated plants were $35.3,31.1$, and $28.7 \%$ lower, respectively, than those of the control plants, when averaged across the three genotypes. Our findings in responses of sugarcane leaf photosynthetic characters to salinity stress are in agreement with those in young rice (Oryza sativa L.) plants by Yeo et al. [43]. They also found that salinity caused the increase in Na level in rice leaves in which high salinity did not affect leaf chlorophyll concentration or $\mathrm{C} i$, but reduced stomatal aperture and $\mathrm{CO}_{2}$ fixation. Our results of the similar $\mathrm{C} i$ for all salt treatments further revealed that both $\mathrm{g}_{\mathrm{s}}$ and $\mathrm{Pn}$ of salt 
treated plants were significantly lower than those of the control plants, which indirectly indicated that decreases in photosynthetic enzyme activities [8,44] and photosynthetic genes down-regulation [45] seem to be major contributors to low leaf Pn for the salt stressed sugarcane plants.

\subsection{Leaf Nonstructural Carbohydrates}

In order to clarify if salinity stress affected photo-assimilate translocation and genotype differences were existed in leaf reducing sugar (glucose + fructose) and sucrose concentrations, leaf disc samples were collected in early morning (8:00-8:30 a.m.) and late afternoon (3:00-3:30 p.m.) at 134 DAP. Analysis of variance (ANOVA) indicated that the main effects of genotype and salinity and their interactions on reducing sugar, sucrose, and total sugar concentrations were highly significant for the morning time samples (Table 2). For the afternoon samples, genotype did not affect reducing sugar; salinity did not affect sucrose; and there were no interactions of genotype $\times$ salinity in sucrose and total sugar concentrations.

Table 2. Leaf reducing sugar (glucose +fructose), sucrose, and total sugar (reducing sugar + sucrose) concentrations in the early morning (8:30 a.m.) and afternoon (3:30 p.m.) of two sugarcane cultivars (CP 00-1101, CP 96-1252) and an Erianthus as affected by salt ( $\mathrm{NaCl})$ concentration (mM) with analysis of variance (ANOVA) of genotype and salt main effects and their interactions ${ }^{\dagger}$.

\begin{tabular}{|c|c|c|c|c|c|c|c|}
\hline \multirow[t]{3}{*}{ Genotype } & \multirow[t]{3}{*}{ Salt Conc. } & \multicolumn{2}{|c|}{ Reducing Sugar } & \multicolumn{2}{|c|}{ Sucrose } & \multicolumn{2}{|c|}{ Total Sugar } \\
\hline & & 8:30 a.m. & 3:30 p.m. & 8:30 a.m. & 3:30 p.m. & $8: 30$ a.m. & 3:30 p.m. \\
\hline & & & & $-(\mu \mathrm{g}$ & $-2)$ & & - \\
\hline \multirow[t]{6}{*}{ CP 00-1101 } & 0 (Control) & $77.8 \mathrm{~b} \ddagger$ & $68.4 \mathrm{ab}$ & $143.4 \mathrm{~b}$ & $306.7 \mathrm{~b}$ & $221.2 \mathrm{c}$ & 375.1 \\
\hline & 38 & $72.4 \mathrm{~b}$ & $89.1 \mathrm{ab}$ & $153.6 \mathrm{~b}$ & $347.0 \mathrm{ab}$ & $226.0 \mathrm{c}$ & 436.2 \\
\hline & 75 & $119.3 \mathrm{a}$ & $94.7 \mathrm{a}$ & $163.6 \mathrm{~b}$ & $357.8 \mathrm{ab}$ & $282.9 \mathrm{bc}$ & 452.5 \\
\hline & 150 & $122.8 \mathrm{a}$ & $75.2 \mathrm{ab}$ & $190.2 \mathrm{~b}$ & $329.8 \mathrm{ab}$ & $313.0 \mathrm{~b}$ & 405.1 \\
\hline & 300 & 87.5 b & $53.9 \mathrm{~b}$ & $302.6 \mathrm{a}$ & $411.6 \mathrm{a}$ & $390.1 \mathrm{a}$ & 465.4 \\
\hline & Mean & $95.9 \mathrm{~B}$ & $76.3 \mathrm{~A}$ & 190.7 B & $350.6 \mathrm{~B}$ & 286.6 B & $426.9 \mathrm{~B}$ \\
\hline \multirow[t]{6}{*}{ СР 96-1252 } & 0 (Control) & 67.7 & $56.8 \mathrm{ab}$ & $287.7 \mathrm{~b}$ & $530.0 \mathrm{ab}$ & $355.4 \mathrm{~b}$ & $586.8 \mathrm{ab}$ \\
\hline & 38 & 68.3 & $45.2 \mathrm{bc}$ & $165.8 \mathrm{c}$ & $473.9 \mathrm{~b}$ & $234.2 \mathrm{c}$ & $519.1 \mathrm{~b}$ \\
\hline & 75 & 68.1 & $66.8 \mathrm{ab}$ & 197.9 c & $587.3 \mathrm{a}$ & $265.9 c$ & $654.2 \mathrm{a}$ \\
\hline & 150 & 65.5 & 49.8 bc & $213.0 \mathrm{c}$ & $555.1 \mathrm{ab}$ & $278.5 c$ & $604.9 \mathrm{ab}$ \\
\hline & 300 & 68.6 & $91.3 \mathrm{a}$ & $406.3 \mathrm{a}$ & $522.4 \mathrm{ab}$ & $474.9 \mathrm{a}$ & $613.7 \mathrm{ab}$ \\
\hline & Mean & $67.6 \mathrm{C}$ & $62.0 \mathrm{~A}$ & $254.1 \mathrm{~A}$ & $533.7 \mathrm{~A}$ & $321.8 \mathrm{~A}$ & $597.7 \mathrm{~A}$ \\
\hline \multirow[t]{6}{*}{ Erianthus } & 0 (Control) & $65.9 c$ & $33.3 c$ & $104.6 \mathrm{~b}$ & 194.6 & $170.5 \mathrm{c}$ & $227.9 \mathrm{~b}$ \\
\hline & 38 & $154.4 \mathrm{a}$ & $76.5 \mathrm{~b}$ & $96.3 \mathrm{~b}$ & 184.1 & $250.7 \mathrm{~b}$ & $260.6 \mathrm{~b}$ \\
\hline & 75 & $116.8 \mathrm{~b}$ & $61.7 \mathrm{bc}$ & $123.3 \mathrm{~b}$ & 220.2 & $240.1 \mathrm{~b}$ & $281.9 \mathrm{~b}$ \\
\hline & 150 & $72.8 \mathrm{c}$ & $55.1 \mathrm{bc}$ & $130.4 \mathrm{~b}$ & 238.1 & $203.2 \mathrm{bc}$ & $293.2 \mathrm{~b}$ \\
\hline & 300 & $152.7 \mathrm{a}$ & $116.6 \mathrm{a}$ & $214.1 \mathrm{a}$ & 246.7 & $366.9 \mathrm{a}$ & $363.3 \mathrm{a}$ \\
\hline & Mean & $112.5 \mathrm{~A}$ & $68.7 \mathrm{~A}$ & $133.7 \mathrm{C}$ & $216.7 \mathrm{C}$ & $246.2 \mathrm{C}$ & $285.4 \mathrm{C}$ \\
\hline \multirow[t]{5}{*}{ Salt main effect } & 0 (Control) & $70.5 \mathrm{~b}$ & $52.8 \mathrm{~b}$ & $178.6 \mathrm{~b}$ & $343.8 \mathrm{~b}$ & $249.1 \mathrm{~b}$ & $396.6 \mathrm{~b}$ \\
\hline & 38 & $98.4 \mathrm{a}$ & $70.3 \mathrm{ab}$ & $138.6 \mathrm{c}$ & $335.0 \mathrm{~b}$ & $237.0 \mathrm{~b}$ & $405.3 \mathrm{~b}$ \\
\hline & 75 & $101.4 \mathrm{a}$ & $74.4 \mathrm{a}$ & $161.6 \mathrm{bc}$ & $388.4 \mathrm{a}$ & $263.0 \mathrm{~b}$ & 462.9 a \\
\hline & 150 & $87.0 \mathrm{a}$ & $60.0 \mathrm{~b}$ & $177.9 \mathrm{~b}$ & $374.3 \mathrm{ab}$ & $264.9 \mathrm{~b}$ & $434.4 \mathrm{ab}$ \\
\hline & 300 & $102.9 \mathrm{a}$ & $87.3 \mathrm{a}$ & 307.7 a & $393.5 \mathrm{a}$ & $410.6 \mathrm{a}$ & 480.8 a \\
\hline \multirow[t]{3}{*}{ ANOVA $\S$} & Genotype (G) & $* * * *$ & ns & $* * * *$ & $* * * *$ & $* * * *$ & $* * * *$ \\
\hline & Salt (S) & $* *$ & $*$ & $* * * *$ & ns & $* * * *$ & $*$ \\
\hline & $\mathrm{G} \times \mathrm{S}$ & $* * * *$ & $* *$ & $* *$ & ns & $* * *$ & ns \\
\hline
\end{tabular}

${ }^{+}$Data are averages of four replications and leaf discs were collected at 134 days after planting. ${ }^{\ddagger}$ Data within a column and a group followed by the same low case letters are not significant $(p>0.05)$; the mean values followed by the same capital letters are not significant for genotype main effect. $\$$ The $n s,{ }^{*}{ }^{* *}, * * *$, and ${ }^{* * * *}$ indicate not significant $(p>0.05)$ and significant at $p \leq 0.05,0.01,0.001,0.0001$ levels, respectively.

Among the three genotypes, CP 96-1252 had the lowest leaf reducing sugar and highest sucrose concentrations in early morning. There were no big differences in leaf reducing sugars between morning and afternoon times. However, leaf sucrose concentration in afternoon was much higher than that in the morning because of leaf photosynthesis. Regardless sampling time within a day, 
the salt stress, especially high salt concentration $(300 \mathrm{mM})$ had much higher nonstructural sugar concentration than the control, particularly in the morning-time leaf samples (Table 2). Therefore, salinity stress also inhabited the photo-assimilate translocation from source to sink, in addition to impact on leaf photosynthesis.

Increased accumulation of sugars has been reported in many other species exposed to salinity, including cotton (Gossypium hirsutum L.) [44], rice [46], and tomatoes (Lycopersicon esculentum L.) [47]. The major motivation for sugar accumulation is that enzymes involved in sugar metabolism are significantly affected under salinity stress condition [48]. Peng et al. [44] had studied that sucrose and starch contents in the cotton main-stem leaves increased with increased soil salinity, because of increases in the activities of sucrose phosphate synthase (SPS) and sucrose synthase (SuSy). Accumulation of sugars is also related to salinity-tolerant mechanisms in many plant species [49]. The increase in cellular osmolarity due to the accumulation of compatible solutes was accompanied by the influx of water into cells, thus providing the turgor required for cell expansion [25]. Studies have shown that when plants grow in salinity soil, the plant tissue sugar concentration increases, and photosynthesis is inhibited due to feedback [50]. In sugarcane, osmotic adjustment indicated that salinity stress led to significant accumulation of osmolytes and sugars [51]. In the present study, there was an increase in sugar accumulation and decrease in photosynthesis under salinity stress, thus, the decline of photosynthesis may be the result of a combination of factors, such as carbon fixation, photo-assimilate translocation, and/or the source-sink relation.

\subsection{Plant Tissue Dry Weights}

There were no differences among genotypes in green leaf dry weight (DW). The main effects of genotype on other biomass parameters (brown leaf DW, stalk DW, and total shoot DW) were significant (Table 3). No interactions of genotype $\times$ salt concentration on plant biomass acumination and partitioning were detected in this study. Overall, Erianthus had lower brown leaf, stalk, and total shoot dry weights than the two sugarcane cultivars.

Table 3. Dry weights (DW) of brown leave, green leaves, stalks, and total shoot of sugarcane cultivars (CP 00-1101, CP 96-1252) and an Erianthus as affected by salt ( $\mathrm{NaCl})$ concentration $(\mathrm{mM})$ at 200 days after planting with analysis of variance (ANOVA) of genotype and salt main effects and their interaction ${ }^{\dagger}$.

\begin{tabular}{|c|c|c|c|c|c|}
\hline \multicolumn{2}{|c|}{ Treatment } & Brown Leaf DW & Green Leaf DW & Stalk DW & Total Shoot DW \\
\hline \multirow[t]{3}{*}{ Genotype } & СР 00-1101 & $54.5 \mathrm{a}^{\ddagger}$ & 56.1 & $150.1 \mathrm{a}$ & 260.7 a \\
\hline & СР 96-1252 & $54.1 \mathrm{a}$ & 59.8 & $119.9 \mathrm{ab}$ & $233.7 \mathrm{a}$ \\
\hline & Erianthus & $36.9 \mathrm{~b}$ & 49.0 & $98.2 \mathrm{~b}$ & $184.1 \mathrm{~b}$ \\
\hline \multirow[t]{5}{*}{ Salt treatment } & 0 (Control) & $58.1 \mathrm{a}$ & $70.6 \mathrm{a}$ & $184.4 \mathrm{a}$ & $313.1 \mathrm{a}$ \\
\hline & 38 & $47.8 \mathrm{ab}$ & $59.7 \mathrm{ab}$ & $134.7 \mathrm{~b}$ & $242.1 \mathrm{~b}$ \\
\hline & 75 & $49.8 \mathrm{ab}$ & $60.7 \mathrm{ab}$ & $143.1 \mathrm{~b}$ & $253.6 \mathrm{~b}$ \\
\hline & 150 & $45.9 \mathrm{~b}$ & $50.0 \mathrm{~b}$ & $112.2 \mathrm{~b}$ & $208.1 \mathrm{~b}$ \\
\hline & 300 & $40.9 \mathrm{~b}$ & $33.7 \mathrm{c}$ & $39.4 \mathrm{c}$ & $113.9 \mathrm{c}$ \\
\hline \multirow[t]{3}{*}{ ANOVA $\S$} & Genotype (G) & $*$ & ns & $*$ & $*$ \\
\hline & Salt (S) & $* *$ & $* *$ & $* *$ & $* *$ \\
\hline & $G \times S$ & ns & ns & ns & ns \\
\hline
\end{tabular}

${ }^{+}$Data are averages of four replications at 200 days after planting. ${ }^{\ddagger}$ Data values within a column and a group followed by the same letters are not significant $(p>0.05)$. \$ The ns, ${ }^{*}$, and ${ }^{* *}$ indicate not significant $(p>0.05)$ and significant at $p \leq 0.05$, and 0.01 levels, respectively.

Total shoot DW decreased as increase in salt concentrations (Table 3). Compared with the control, the shoot DWs of the 38, 75, 150, and $300 \mathrm{mM}$ salt treated plants decreased 22.7, 19.0, 33.5, and 63.6\%, respectively. Although salinity reduced dry matter accumulations of brown leaves, green leaves, and stalks, stalk DW had the most reduction among the three plant tissues (Table 3). When salt concentration was $300 \mathrm{mM}$, DWs of brown leaves, green leaves, and stalks were $70.4,47.7$, and $21.4 \%$ of 
the control plants, respectively. A remarkable reduction in dry matter yield was reported in gramineous plants including sugarcane exposed to salinity stress [3,46,52]. Our result of stalk biomass having most reduction by salinity among three shoot components is in consistent with an early report [53] in which among the percentage of sugarcane germination, rate of stem growth, and dry weight of root, used for evaluating varietal resistance to soil salinity, the rate of stem growth appeared to be the most significant sensitive to salinity stress. Akhtar et al. [54] suggested that reduction in overall growth of the sugarcane leaves appeared due to effect of salinity, primarily on the gas exchange parameter and secondarily on the anatomical features.

Our results further revealed that high salinity significantly reduced not only sugarcane shoot growth, but also root growth (Figure 4A). Sugarcane CP 96-1252 had the greatest and CP 00-1101 had the smallest shoot-to-root ratio under the non-salinity (control) conditions. However, the ratios did not differ among three genotypes under the 300-mM salt treatment condition (Figure 4B). With increasing concentration of $\mathrm{NaCl}$, the sugarcane root growth was more adversely affected than was shoot growth [3]. Results of the present study also indicated that the growth of the underground part of sugarcane was also inhibited by salinity, but CP 96-1252 seemed to be more sensitive to salinity stress than CP 00-1101 in shoot/root ratio (Figure 4).

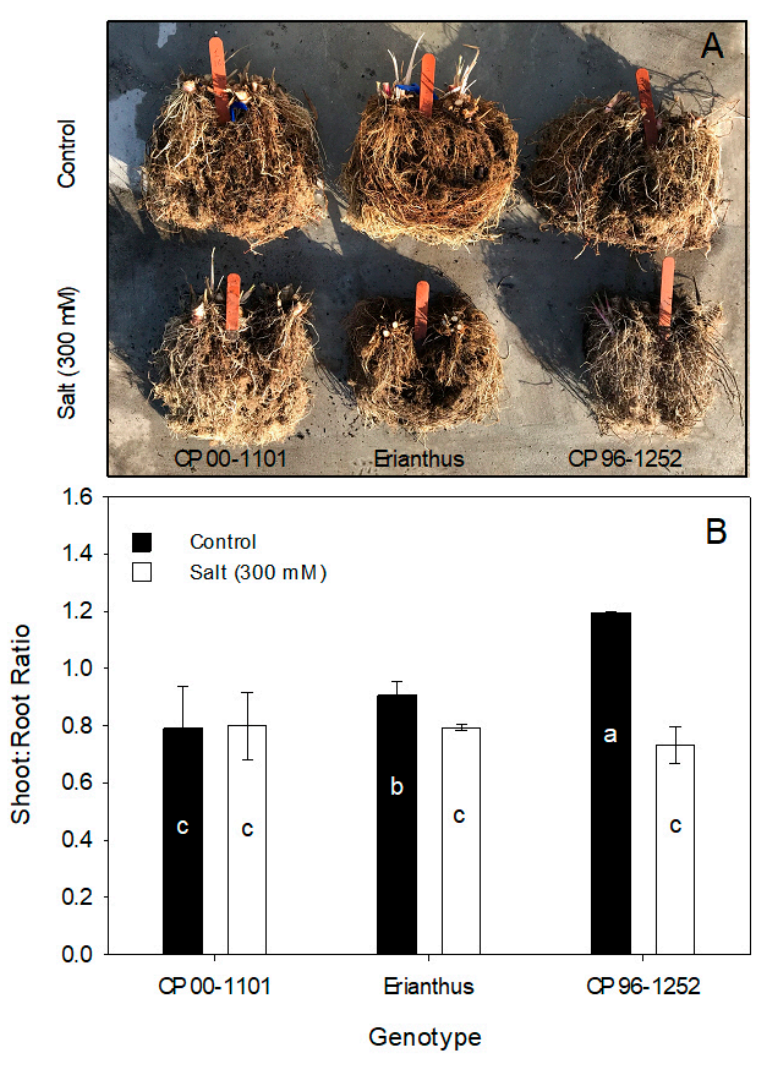

Figure 4. Effect of salinity (300 $\mathrm{mM}$ of $\mathrm{NaCl}$ added) on (A) roots and (B) shoot to root dry weight ratio of two sugarcane cultivars (CP 00-1101, CP 96-1252) and an Erianthus at 200 days after planting. Data are means \pm SE $(n=4)$. The values with the same letters are not significant $(p>0.05)$.

\section{Conclusions}

Effects of salinity on sugarcane growth, photosynthesis, and photo-assimilate translocation depended on the soil salt concentration. Leaf Pn of sugarcane plants treated with $38 \mathrm{mM}$ of salt did not differ from that of the control, but plants treated with the 75, 150, and $300 \mathrm{mM}$ salt concentrations had 12.7, 18.7, and 35.3\% lower Pn, respectively, than the control plants. This study revealed that the sugarcane low leaf Pn due to salinity was associated with not only the decrease in stomatal conductance, 
but also non-stomatal factors (i.e., the carbon fixation enzyme activities). High salt concentration depressed sugar translocation from leaves to other tissues. Among the three growth traits measured, the number of tillers per plant was the most sensitive, while the number of nodes on the primary stalk was the most tolerant to salt concentration. Depressed plant growth, leaf $\mathrm{Pn}$, and photo-assimilate translocation from salinity resulted in low shoot dry matter accumulation. These findings can improve our knowledge in better understanding of some carbon metabolic and physiological mechanisms of salinity influence on sugarcane growth and yields. Further studies are needed to investigate saline effects on sugarcane flowering and flower quality in the breeding programs.

Author Contributions: Data collection, D.Z. and X.G.; formal analysis, D.Z., K.Z., and A.M.; investigation, X.G. and D.Z.; supervision, D.Z.; writing original draft, D.Z., K.Z., and A.M.; review and editing, D.Z. All authors have read and agreed to the published version of the manuscript.

Funding: This research received no external funding.

Acknowledgments: We thank Philip Aria for his valuable technical assistance and skilled data collection and management. This research has been presented at the 2018 American Society of Sugar Cane Technologists' (ASSCT) Joint Annual meeting. Use of trade or commercial product names is for informational purpose only and does not imply endorsement by the United States Department of Agriculture to the exclusion of any other product that may be suitable.

Conflicts of Interest: The authors declare no conflict of interest.

\section{References}

1. Wahid, A.; Rao, A.; Rasul, E. Identification of salt tolerance traits in sugarcane lines. Field Crops Res. 1997, 54, 9-17. [CrossRef]

2. Shrivastava, P.; Kumar, R. Soil salinity: A serious environmental issue and plant growth promoting bacteria as one of the tools for its alleviation. Saudi J. Biol. Sci. 2015, 22, 123-131. [CrossRef]

3. Shomeili, M.; Nabipour, M.; Meskarbashee, M.; Memari, H.R. Evaluation of sugarcane (Saccharum officinarum L.) somaclonals tolerance to salinity via in vitro and in vivo. HAYATI J. Biosci. 2011, 18, 91-96. [CrossRef]

4. Simões, W.L.; Calgaro, M.; Coelho, D.S.; dos Santos, D.B.; de Souza, M.A. Growth of sugar cane varieties under salinity. Rev. Ceres 2017, 63, 265-271. [CrossRef]

5. Bernstein, L. Effects of salinity and sodality on plant growth. Ann. Rev. Phytopathol. 1975, 13, 295-312. [CrossRef]

6. Bernstein, L. Salt tolerance of plants. U. S. Dep. Agric. Agric. Inf. Bull. 1964, 283, 23.

7. Brenes, M.; Pérez, J.; González-Orenga, S.; Solana, A.; Boscaiu, M.; Prohens, J.; Plazas, M.; Fita, A.; Vicente, O. Comparative studies on the physiological and biochemical responses to salt stress of eggplant (Solanum melongena) and its rootstock S. torvum. Agriculture 2020, 10, 328. [CrossRef]

8. Courtney, P.L.; Cousins, A.B.; Offermann, S.; Okita, T.W.; Edwards, G.E. The effects of salinity on photosynthesis and growth of the single-cell C4 species Bienertia sinuspersici (Chenopodiaceae). Photosynth. Res. 2010, 106, 201-214.

9. Bliss, M.B.; Smart, C.M.; Maricle, K.L.; Maricle, B.R. Effects of increasing salinity on photosynthesis and plant water potential in Kansas salt marsh species. Trans. Kans. Acad. Sci. 2019, 122, 49-58.

10. Munns, R.; James, R.A.; Lauchil, A. Approaches to increasing the salt tolerance of wheat and other cereals. J. Exp. Biol. 2006, 57, 1025. [CrossRef]

11. Sudhir, P.; Murthy, S.D.S. Effects of salt stress on basic processes of photosynthesis. Photosynthetica 2004, 42, 481-486. [CrossRef]

12. Hare, P.D.; Cress, W.A.; Staden, J.V. Dissecting the roles of osmolyte accumulation during stress. Plant Cell Environ. 1998, 21, 535. [CrossRef]

13. Hasegawa, P.M.; Bressan, R.A.; Zhu, J.K.; Bohnert, H.J. Plant cellular and molecular responses to high salinity. Ann. Rev. Plant Physiol. Plant Mol. Biol. 2000, 51, 463-499. [CrossRef] [PubMed]

14. Huaser, M.T.; Aufsatz, W.; Jonak, C.; Luschnig, C. Transgenerational epigenetic inheritance in plants. Biochim. Biophys. Acta 2011, 1809, 459-468. [CrossRef] [PubMed]

15. Bernstein, L.; Clark, R.A.; Francois, L.E.; Derderian, M.D. Salt tolerance of N. Co. varieties of sugar cane. II. Effects of soil salinity and sprinkling on chemical composition. Agron. J. 1966, 58, 503-507. [CrossRef]

16. Hussain, A.; Khan, Z.I.; Ashraf, M.; Rashid, M.H.; Akhtar, M.S. Effect of salt stress on some growth attributes of sugarcane cultivars CP-77-400 and COJ-84. Int. J. Agric. Biol. 2004, 6, 188-191. 
17. Christy, P.M.; Preetha, R.D.; Vasantha, S.; Divya, D. Biochemical and molecular analysis of sugarcane genotypes response to salinity and drought. Int. J. Appl. Biol. Pharmaceut. Technol. 2013, 4, 210-218.

18. de Almeida Moreira, B.R.; da Silva Viana, R.; de Figueiredo, P.A.M.; Lisboa, L.A.M.; Miasaki, C.T.; Magahães, A.C.; Ramos, S.B.; de Almeida Viana, C.R.; Trindade, V.D.R.; May, A. Glyphosate plus carboxylic compounds boost activity of free radical-scavenging enzymes in sugarcane. Agriculture 2020, 10, 106. [CrossRef]

19. Lingle, S.E.; Wiegand, C.L. Soil salinity and sugarcane juice quality. Field Crops Res. 1997, 54, $259-268$. [CrossRef]

20. Wiedenfeld, B. Effects of irrigation water salinity and electrostatic water treatment for sugarcane production. Agric. Water Manag. 2008, 95, 85-88. [CrossRef]

21. Zhao, D. The USDA-ARS Sugarcane Field Station in Canal Point, Florida: 100 years of scientific research and sugarcane cultivar development. Sugar J. 2020, 82, 13-21.

22. McCord, P.H.; (USDA-ARS Sugarcane Field Station, Canal Point, FL, USA). Unpublished work. 2015.

23. Gandonou, C.B.; Gnancadja, L.S.; Abrini, J.; Skali-Senhaji, N. Salinity tolerance of some sugarcane (Saccharum sp.) cultivars in hydroponic medium. Int. Sugar J. 2012, 114, 190-196.

24. Padmathilake, K.R.E.; Wickramaarachchi, V.N.; Anver, M.A.M.S.; Bandara, D.C. Biological and economical feasibility of growing mint (Mentha sylvestris), mustard (Brassica integrifolia) and asamodagam (Trachyspermum involucratum) under hydroponics. Trop. Agric. Res. 2007, 19, 193-201.

25. Hussain, A.; Khan, Z.I.; Rashid, M.H.; Ashraf, M.; Akhtar, M.S. Soil salinity effects on sugarcane productivity, biochemical characteristics, and invertase activity. Pak. J. Life Social Sci. 2003, 1, 114-121.

26. Berding, N.; Roach, B.T. Germplasm collection, maintenance, and use. In Sugarcane Improvement through Breeding; Heinz, D.J., Ed.; Elsevier: Amsterdam, The Netherlands, 1987; pp. 143-210.

27. Edmé, S.J.; Tai, P.Y.P.; Glaz, B.; Gilbert, R.A.; Miller, J.D.; Davidson, J.O.; Dunckelman, J.W.; Comstock, J.C. Registration of 'CP 96-1252' sugarcane. Crop Sci. 2005, 45, 423. [CrossRef]

28. Gilbert, R.A.; Comstock, J.C.; Glaz, B.; Edmé, S.J.; Davidson, R.W.; Glynn, N.C.; Miller, J.D.; Tai, P.Y.P. Registration of 'CP 00-1101' sugarcane. J. Plant Reg. 2008, 2, 95-101. [CrossRef]

29. VanWeelden, M.; Rice, R.; Davidson, R.W.; Swanson, S. Sugarcane variety census: Florida 2016. Sugar J. 2017, $80,12-24$.

30. Zhao, D.; Glaz, B.; Irey, M.S.; Hu, C.J. Sugarcane genotype variation in leaf photosynthesis properties and yield as affected by mill mud application. Agron. J. 2015, 107, 506-514. [CrossRef]

31. Zhao, D.; Oosterhuis, D.M. Cotton responses to shade at different growth stages: Nonstructural carbohydrate composition. Crop Sci. 1998, 38, 1196-1203. [CrossRef]

32. Zhao, D.; MacKown, C.T.; Starks, P.J.; Kindiger, B.K. Rapid analysis of nonstructural carbohydrate components in grass forage using microplate enzymatic assays. Crop Sci. 2010, 50, 1537-1545. [CrossRef]

33. Zhao, D.; Glaz, B.; Comstock, J.C. Sugarcane leaf photosynthesis and growth characters during development of water-deficit stress. Crop Sci. 2013, 53, 1066-1075. [CrossRef]

34. SAS Institute. The SAS system for Windows. In Release 9.0; SAS Inst.: Cary, NC, USA, 2002.

35. Netondo, G.W.; Onyango, J.C.; Beck, E. Sorghum and salinity: II. Gas exchange and chlorophyll fluorescence of sorghum under salt stress. Crop Sci. 2004, 44, 806-811. [CrossRef]

36. Mehta, P.; Jajoo, A.; Mathur, S.; Bharti, S. Chlorophyll a fluorescence study revealing effects of high salt stress on Photosystem II in wheat leaves. Plant Physiol. Biochem. 2010, 48, 16-20. [CrossRef]

37. Sun, Z.W.; Ren, L.K.; Fan, J.W.; Li, Q.; Wang, K.J.; Guo, M.M.; Wang, L.; Li, J.; Zhang, G.X.; Yang, Z.Y.; et al. Salt response of photosynthetic electron transport system in wheat cultivars with contrasting tolerance. Plant Soil Environ. 2016, 62, 515-521. [CrossRef]

38. Belkhodja, R.; Morales, F.; Abadia, A.; Gomezaparisi, J.; Abadia, J. Chlorophyll fluorescence as a possible tool for salinity tolerance screening in barley (Hordeum vulgare L). Plant Physiol. 1994, 104, 667-673. [CrossRef] [PubMed]

39. Vasantha, S.; Venkataramana, S.; Rao, P.N.G.; Gomathi, R. Long term salinity effect on growth, photosynthesis and osmotic characteristics in sugarcane. Sugar Tech. 2010, 12, 5-8. [CrossRef]

40. Tahjib-UI-Arif, M.; Sohag, A.A.M.; Afrin, S.; Bashar, K.K.; Afrin, T.; Mahamud, A.S.U.; Polash, M.A.S.; Hossain, M.T.; Sohel, M.A.T.; Brestic, M.; et al. Differential response of sugar beet to long-term mild to severe salinity in a soil-pot culture. Agriculture 2019, 9, 223. [CrossRef]

41. Sharwood, R.E.; Sonawane, B.V.; Ghannoum, O. Photosynthetic flexibility in maize exposed to salinity and shade. J. Exp. Bot. 2014, 65, 3715-3724. [CrossRef] 
42. Yan, K.; Shao, H.; Shao, C.; Chen, P.; Zhao, S.; Brestic, M.; Chen, X. Physiological adaptive mechanisms of plants grown in saline soil and implications for sustainable saline agriculture in coastal zone. Acta Physiol. Plant. 2013, 35, 2867-2878. [CrossRef]

43. Yeo, A.R.; Caporn, S.J.M.; Floers, T.J. The Effect of salinity upon photosynthesis in rice (Oryza sativa L.): Gas exchange by individual leaves in relation to their salt content. J. Exp. Bot. 1985, 36, 1240-1248. [CrossRef]

44. Peng, J.; Liu, J.R.; Zhang, L.; Luo, J.Y.; Dong, H.L.; Ma, Y.; Zhao, X.H.; Chen, B.L.; Sui, N.; Zhou, Z.G.; et al. Effects of soil salinity on sucrose metabolism in cotton leaves. PLoS ONE 2016, 11, e0156241. [CrossRef]

45. Chaves, M.M.; Flexas, J.; Pinheiro, C. Photosynthesis under drought and salt stress: Regulation mechanisms from whole plant to cell. Ann. Bot. 2009, 103, 551-560. [CrossRef]

46. Wattana, P.; Thitisaksakul, M. Effects of salinity stress on growth and carbohydrate metabolism in three rice (Oryza sativa L.) cultivars differing in salinity tolerance. Indian J. Exp. Biol. 2008, 46, 736-742.

47. Yin, Y.G.; Kobayashi, Y.; Sanuki, A.; Kondo, S.; Fukuda, N.; Ezura, H.; Sugaya, S.; Matsukura, C. Salinity induces carbohydrate accumulation and sugar regulated starch biosynthetic genes in tomato (Solanum lycopersicum L. cv. 'Micro-Tom') fruits in an ABA- and osmotic stress-independent manner. J. Exp. Bot. 2010, 61, 563-574. [CrossRef] [PubMed]

48. Gomathi, R.; Thandapani, P.V. Sugar metabolism and carbon partitioning of sugarcane genotypes under salinity stress condition. Sugar Tech. 2004, 6, 151-158. [CrossRef]

49. Gupta, B.; Huang, B. Mechanism of salinity tolerance in plants: Physiological, biochemical, and molecular characterization. Int. J. Genom. 2014, 701596. [CrossRef] [PubMed]

50. Munns, R. Physiological process limiting plant growth in saline soils: Some dogmas and hypotheses. Plant Cell Environ. 1993, 16, 15-24. [CrossRef]

51. Vikas, Y.P.; Bhargava, S.; Suprasanna, P. Salt and drought tolerance of sugarcane under iso-osmotic salt and water stress: Growth, osmolytes accumulation, and antioxidant defense. J. Plant Interact. 2011, 6, 275-282.

52. Sultana, N.; Ikeda, T.; Itoh, R. Effect of $\mathrm{NaCl}$ salinity on photosynthesis and dry matter accumulation in developing rice grains. Environ. Exp. Bot. 1999, 42, 211-220. [CrossRef]

53. Liu, L.J. Salinity effects on sugarcane germination, growth, and root development. J. Agric. Univ. Puerto Rico. 1967, 51, 201-209. [CrossRef]

54. Akthar, S.; Wahid, A.; Akram, M.; Rahul, V.E. Some growth, photosynthetic and anatomical attributes of sugarcane genotypes under $\mathrm{NaCl}$ salinity. Int. J. Agric. Biol. 2001, 3, 439-443.

Publisher's Note: MDPI stays neutral with regard to jurisdictional claims in published maps and institutional affiliations.

(C) 2020 by the authors. Licensee MDPI, Basel, Switzerland. This article is an open access article distributed under the terms and conditions of the Creative Commons Attribution (CC BY) license (http://creativecommons.org/licenses/by/4.0/). 